\title{
Endovascular aortic aneurysm repair: a method of treatment of abdominal aortic aneurysm stent implantation
}

\author{
Ana Bognar*, \\ Ivana Raič \\ University of Rijeka School \\ of Medicine, University \\ Hospital Centre Rijeka, \\ Rijeka, Croatia
}

KEYWORDS: abdominal aortic aneurysm, endovascular aortic aneurysm repair, treatment. CITATION: Cardiol Croat. 2016;11(3-4):130. | DOI: http://dx.doi.org/10.15836/ccar2016.130

*ADDRESS FOR CORRESPONDENCE: Ana Bognar, Klinički bolnički centar Rijeka, T. Strižića 3, HR-51000 Rijeka, Croatia / Phone: +385-51-407-129 / E-mail: ana.bognar@gmail.com

ORCID: Ana Bognar, http://orcid.org/0000-0002-9111-4198 • Ivana Raič, http://orcid.org/0000-0003-4297-1457

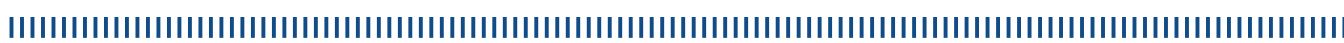

Abdominal aortic aneurysm, along with myocardial infarction and stroke is one of the most common diseases of blood vessels, and it is estimated that almost $10 \%$ of the male population over age 60 has an aneurysm. The mortality of ruptured abdominal aortic aneurysm in some cases is growing to an alarming $90 \%$. With the former techniques of treating aneurysms, such as conservative (drug therapy) treatment and open surgery, in 1991 the endovascular aortic repair was introduced as a significantly less invasive method than surgery.

The main difference between classic open surgery and endovascular stenting is that in the former method the stent is placed into the aortic aneurysm without the need of opening the abdomen and removing aortic tissue. Therefore, the recovery time is faster and the patients are released from the hospital within a week. Because of the mentioned advantages that endovascular repair of aneurysms has over traditional open surgery it can be mentioned advantages that endovascular repair of aneurysms has over traditional open surgery it can be considered as a valid alternative in the treatment of abdominal aortic aneurysms in specific indications. ${ }^{1}$
RECEIVED:

February 9, 2016

ACCEPTED:

February 20, 2016

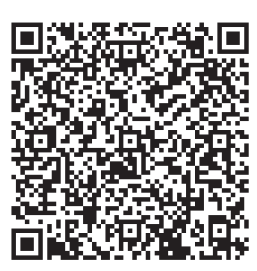

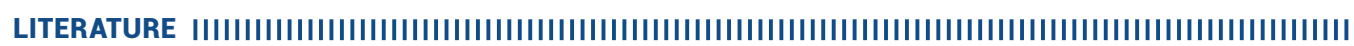

1. England A, Mc Williams R. Endovascular aortic aneurysm repair (EVAR). Ulster Med J. 2013 Jan;82(1):3-10. PubMed:http://www.ncbi.nlm.nih.gov/pubmed/23620623 